\title{
DNase I treated DNA-PCR based detection of food pathogens immobilized by metal hydroxides
}

\author{
Huong Thi Thu Do • Alfredo J. Anceno • \\ Sudip K. Rakshit
}

Published online: 25 April 2009

(C) Springer Science+Business Media B.V. 2009

\section{Erratum to: World J Microbiol Biotechnol DOI 10.1007/s11274-009-0031-5}

Unfortunately the article published under the doi:10.1007/ s11274-009-0031-5 has following three corrections.

The second author's name had been misspelled. The correct version is Alfredo J. Anceno and not Alfredo J. Anceno II as published.

In the original publication under the Materials and methods section, the first line of the subsection "Bacterial strains" should reads as

Salmonella typhimurium ATCC 13311, Escherichia coli O157:H7, Listeria monocytogenes and Escherichia coli wild type were obtained from Department of Medical Science Technology (DMST), Nonthaburi, Thailand.
Instead of

Salmonella typhimurium ATCC 13311, Escherichia coli O157:H7, Listeria monocytogenes and Escherichia coli wild type were obtained from BIOTEC, NASTDA, Thailand.

The Acknowledgements section in this article should read as

Acknowledgment Huong Thi Thu Do is the receipient of the Vietnamese Overseas Scholarship

Instead of

Acknowledgments Huong Thi Thu Do is the receipient of the Vietnamese Overseas Scholarship. We gratefully acknowledge BIOTEC, NASTDA, Thailand for supplying bacterial materials.

The online version of the original article can be found under doi:10.1007/s11274-009-0031-5.

H. T. T. Do · A. J. Anceno - S. K. Rakshit

Asian Institute of Technology, P.O. Box 4, Klong Luang,

Pathumthani 12120, Thailand

H. T. T. Do $(\bowtie)$

Post Harvest Science and Technology Division, Japan International Research Center for Agricultural Sciences (JIRCAS), 1-1 Ohwashi, Tsukuba, Ibaraki 305-8686, Japan e-mail: huongdo@jircas.affrc.go.jp 